\title{
Negative Regulation of Degradation of Adhesion Factor
}

National Cancer Institute

\section{Source}

National Cancer Institute. Negative Regulation of Degradation of Adhesion Factor. NCI

Thesaurus. Code C40681.

Adhesion Factor Stabilization inhibits conjug ation, transport, oxidation, or proteolysis of cell surface proteins involved in cell-cell or cell-matrix attachment. Such stabilization can alter maintenance of tissue integration, wound healing, cellular migrations, and metastasis. 